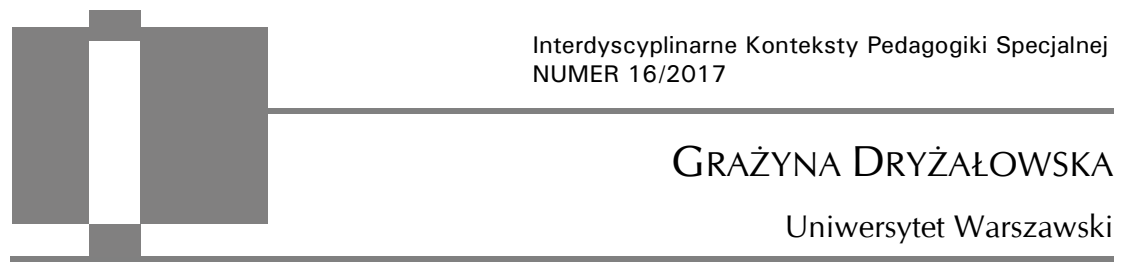

\title{
Integracja edukacyjna z innej perspektywy
}

ABSTRACT: Grażyna Dryżałowska, Integracja edukacyjna z innej perspektywy [Educational integration from the different perspective]. Interdyscyplinarne Konteksty Pedagogiki Specjalnej, nr 16, Poznań 2017. Pp. 33-61. Adam Mickiewicz University Press. ISSN 2300-391X

Educational Integration changed the social situation of persons with disability starting the sequence of new factors setting assessments for her. Getting to know their interrelationships and conditioning seems significant for current determining laying individuals of the disabled and wider social contexts in area which are accommodating oneself reasons for taking action ill-advised, in consequence faked, for their public integration.

KEY WORDS: educational integration, social integration, persons with disability, effectiveness of integration action, education, inclusion

\section{Wstęp}

Integracja edukacyjna - upowszechnienie jej idei (poprzedzone licznymi dyskusjami, sporami), jej rozwój koncepcyjny, teoretyczny i wreszcie praktyczna realizacja zaprzeczyły pielęgnowanemu przez stulecia przekonaniu o słuszności segregacyjnych i ochronnych strategii w edukacji osób niepełnosprawnych. Stały się one dowodem, że najskuteczniejszą drogą integracji społecznej osób z niepełnosprawnością jest wspólna nauka dzieci pełno- i niepełnosprawnych. Nie oznacza to jednak, że dotychczasowe efekty, po niemal 40 latach wdrażania integracyjnych form edukacji w naszym kraju, za- 
dowalają wszystkich - teoretyków, badaczy, praktyków czy wreszcie środowisko osób z niepełnosprawnością i ich najbliższych.

Próby umocnienia słuszności tej koncepcji zaowocowały licznymi projektami badawczymi, których wyniki dostarczają argumentów za, ale też przeciw tej formie edukacji, szczególnie w odniesieniu do osób z głębszym stopniem niepełnosprawności.

Badania nad efektywnością integracyjnego kształcenia, tak w kraju, jak i za granicą, zazwyczaj obejmują dwa obszary: osiągnięć szkolnych (poznawczych) uczniów niepełnosprawnych wybranych formach integracyjnej edukacji (w szkole, klasie integracyjnej lub masowej) oraz pozycji zajmowanej przez ucznia w strukturze klasy $^{1}$. Stosunkowo rzadko te dwa obszary uzupełnia diagnoza emocjonalnego funkcjonowania uczniów niepełnosprawnych w szkole i w życiu dorosłym.

Realizowane badania nad efektywnością integracji edukacyjnej odnoszą się zatem przede wszystkim do oceny stopnia akceptacji uczniów niepełnosprawnych przez społeczność szkolną - nauczycieli, uczniów pełnosprawnych i ich rodziców lub oceny efektów nauczania uczniów niepełnosprawnych $\mathrm{w}$ systemie integracyjnym i specjalnym².

Wyniki tych badań są zazwyczaj niejednoznaczne, nie są zatem w stanie potwierdzić/zaprzeczyć celowości edukacji integracyjnej dla społecznej integracji uczniów, którzy korzystają z takich edukacyjnych rozwiązań. Powód raczej oczywisty, wynikający z wyko-

${ }^{1}$ J. Lipińska-Lokś, Zmiany stosunków między dziećmi petnosprawnymi i dziećmi $z$ niepetnosprawnościa w klasach integracyjnych, Wydawnictwo Uniwersytetu Zielonogórskiego, Zielona Góra 2011; K. Barłóg, Wspomaganie rozwoju dzieci niepetnosprawnością intelektualna w stopniu lekkim w różnych formach edukacji wczesnoszkolnej, Wydawnictwo Uniwersytetu Rzeszowskiego, Rzeszów 2008.

2 K. Barłóg, op. cit.; A. Firkowska-Mankiewicz, Spór o inteligencję człowieka. Dziedziczność czy środowisko, Wydawnictwo Polska Akademia Nauk. Instytut Filozofii i Socjologii, Warszawa 1993; G. Szumski, Wokót edukacji włączającej. Efekty kształcenia uczniów z niepetnosprawnościa intelektualna w stopniu lekkim w klasach specjalnych, integracyjnych $i$ ogólnodostępnych, Wydawnictwa Akademii Pedagogiki Specjalnej im. Marii Grzegorzewskiej w Warszawie, Warszawa 2010. 
rzystanej w nich metodologii badań. Zwykle odnoszącej się do wybranych grup osób z niepełnosprawnością, różnych obszarów ich funkcjonowania, etapów wychowania i edukacji lub form kształcenia - integracyjnych bądź specjalnych. Zgromadzona w nich obszerna, ale podzielona wiedza nie ułatwia diagnozy mechanizmów społecznej integracji we współczesnej rzeczywistości.

Badania nad znaczeniem integracyjnych form edukacji szkolnej dla integracji społecznej w dorosłym życiu osób niepełnosprawnych wciąż są wyjątkiem³ ${ }^{3}$

Zadaniem integracji $\mathrm{w}$ nowoczesnym społeczeństwie jest $\mathrm{z}$ jednej strony wzajemne uzależnienie względnie samodzielnych podsystemów - ich unifikacja i ograniczenie stopni swobody, a z drugiej - usamodzielnienie części wobec całości. Znaczenie części $\mathrm{w}$ zintegrowanym systemie zależy zatem lub jest wyznaczone poziomem jej usamodzielnienia, a więc autonomii.

Łączenie - koordynacja autonomicznych jednostek przy zachowaniu ich autonomii jest możliwa, jak stwierdza Aaron T. Beck (1993), tylko przez nowy mechanizm integracji. Funkcję takiego mechanizmu może przejąć jednostkowa biografia, własne życie, gdyż jest to jedyna stała linia łącząca zróżnicowane propozycje i role społeczne, czasowo ograniczone przynależności, zaangażowania wewnątrz odmiennych ugrupowań i sytuacji. [...] Jednostka tworzy zatem zbiór wielorakich, parcjalnych, czasowo ograniczonych wzorów zachowań, tożsamości i systemów orientacji społeczno-kulturowej, które odpowiadają aktualnie "odwiedzanym" segmentom społecznym. Własna biografia jest miejscem integracji tychże częściowych tożsamości

Współczesny model integracji społecznej stawia zatem przed integracyjnymi formami edukacji nowe pytania o rehabilitację, metody usprawniania dzieci i młodzieży niepełnosprawnej, o kompeten-

${ }^{3}$ A. Firkowska-Mankiewicz, op. cit., G. Dryżałowska, Integracja edukacyjna a spoŁeczna. Satysfakcja z życia osób niedosłyszących, Wydawnictwo Uniwersytetu Warszawskiego, Warszawa 2015.

4 S. Krzychała, Ryzyko własnego życia. Indywidualizacja w późnej nowoczesności, Wydawnictwo Naukowe DSW, Wrocław 2007, s. 117. 
cje niezbędne do nowych wyzwań To niezmiernie istotna perspektywa w refleksji nad pedagogicznymi modelami wspierania uczniów $\mathrm{w}$ integracyjnych formach edukacji i możliwym niezbędnym modelowaniu/zmianie kryteriów społecznej selekcji i to ona została założona $\mathrm{w}$ tytule tego opracowania. Próba prześledzenia zmian, które w mniej lub bardziej bezpośredni sposób dokonały się i wciąż się dokonują pod wpływem idei wspólnej edukacji, istotnych dla położenia oraz społecznej alokacji osób z niepełnosprawnością, jest celem tego opracowania. Zmian, których prześledzenie, mam taką nadzieję, rzuci nowe światło także na te obszary integracyjnej edukacji, którym wciąż stawia się zarzut ich adaptacyjnego charakteru i raczej postulowanych niż rzeczywistych efektów i identyfikację czynników takie opinie uzasadniających.

\section{Co zmieniła integracyjna edukacja? Zakładane a uzyskane efekty integracyjnej edukacji}

Osoby z niepełnosprawnością zawsze były częścią szkolnej społeczności, ale dopiero integracja edukacyjna, oficjalnie zapoczątkowana w 1989 r. powołaniem w Warszawie pierwszego przedszkola integracyjnego ${ }^{5}$ uprawomocniła ich obecność w szkolnictwie ogólnodostępnym i przyniosła zmiany dotychczas w historii wspierania rozwoju i edukacji osób z niepełnosprawnością niespotykane.

Integracja edukacyjna zmieniła społeczną sytuację osób z niepełnosprawnością, uruchamiając szereg nowych czynników wyznaczających jej wymiary. Poznanie ich wzajemnych zależności i uwarunkowań wydaje się istotne dla określenia obecnego położenia jednostek niepełnosprawnych i szerszych kontekstów społecznych w obszarze których lokują się przyczyny podejmowania nietraf-

${ }^{5}$ J. Łysek, Kształcenie integracyjne w Polsce i w krajach Unii Europejskiej, "Nauczyciel i Szkoła” 2002, nr 1-2; J. Popławska, B. Sierpińska, "Zacznijmy razem" - dzieci specjalnej troski w szkole podstawowej. Poradnik dla nauczycieli szkót integracyjnych, WSiP, Warszawa 2001. 
nych, w konsekwencji pozorowanych działan, na rzecz ich społecznej integracji.

Obecnie systemem integracyjnych form edukacji objętych jest 174338 (stan na 19 września 2015 r.) uczniów z w różnym wieku i z różnym rodzajem niepełnosprawności.

- w przedszkolach - 12363000 - 123630 dzieci z niepełnosprawnościami (1\% ogółu) - 191 placówek przedszkolnych specjalnych do nich uczęszczało 3200 dzieci z niepełnosprawnością;

- w szkołach podstawowych: ogółem 63,0 tys. uczniów ze specjalnymi potrzebami edukacyjnymi - w tym 39,5 tys. (w oddziałach specjalnych 2,2\%, w integracyjnych 37,1\% i szkołach ogólnodostępnych 60,7\%), a 23,6 tys. w szkołach specjalnych;

- w gimnazjach: ogółem 47,2 tys. uczniów ze specjalnymi potrzebami edukacyjnymi - w tym 22,1 tys. (w oddziałach specjalnych 3,1\%, w integracyjnych 31,8\% i szkołach ogólnodostępnych $65,2 \%)$, a 25,1 tys. w szkołach specjalnych (53,2\% wszystkich uczniów ze specjalnymi potrzebami edukacyjnymi);

- w szkołach ponadgimnazjalnych: ogółem 26,5 tys. uczniów ze specjalnymi potrzebami edukacyjnymi - w tym 8900 (w oddziałach specjalnych 2,0 \%, w integracyjnych 20,7\% i szkołach ogólnodostępnych 77,4\%) - w tym w liceach ogólnokształcących 39,6\% oraz zasadniczych szkołach zawodowych 35,0\%, a 26,5 tys. w szkołach specjalnych zawodowych 12,9 tys. $(48,9 \%)$ i przysposabiających do pracy 11,0 tys. $(41,7 \%)$;

- w technikach: ogółem 3000 uczniów ze specjalnymi potrzebami edukacyjnymi - w tym 2141 (w oddziałach specjalnych 0,8\%, w integracyjnych 8,4\% i szkołach ogólnodostępnych 90,8\%), a 808 w technikach specjalnych;

- w szkołach policealnych: ogółem 475 uczniów ze specjalnymi potrzebami edukacyjnymi - w tym 80 (w oddziałach specjalnych 10,5\%, w integracyjnych 25,0\% i szkołach ogólnodostępnych 64,5\%), a 339 uczniów w szkołach specjalnych ${ }^{6}$.

6 Źródło: GUS stan na 19.09.2015 r. 
Z danych tych wynika, że poza szkolnictwem zawodowym, na pozostałych etapach edukacji w integracyjnych formach edukacji kształci się porównywalna jak w systemie segregacyjnym liczba uczniów z różnymi rodzajami niepełnosprawności. Szkolnictwo otwarte jest więc powszechną formą kształcenia uczniów ze specjalnymi potrzebami edukacyjnymi.

Przytoczone liczby potwierdzają więc zmiany jakie są zasługą integracyjnych form edukacji.

- Od integracji ukrytej poprzez możliwość w latach 1991-1993 do prawa wspólnej nauki w 1999 r.

- Od ignorowania potrzeb edukacyjnych uczniów z niepełnosprawnością w integracji ukrytej do obowiązku ich zaspokajania.

- Od placówek wczesnej diagnozy i wspierania rozwoju dzieci upośledzonych umysłowo do programu Wczesnego Wspierania Rozwoju dla wszystkich dzieci z orzeczeniem o niepełnosprawności lub zagrożonych niepełnosprawnością.

- Od administracyjnych decyzji o drodze edukacji opartej o rodzaj i stopień niepełnosprawności do możliwości wyboru środowiska edukacyjnego przez ucznia lub jego prawnych opiekunów (najmniej ograniczającego/najbardziej stymulującego).

- Od określeń dyskryminujących (uczeń niepełnosprawny) do niedyskryminujących (uczeń ze specjalnymi potrzebami edukacyjnymi).

W ich efekcie można było oczekiwać, że integracyjny system kształcenia urealni szanse uczniów z niepełnosprawnością na udział w życiu społeczności szkolnej - ich integrację ze społecznością szkolną, ale także przygotuje do uczestnictwa w ważnych obszarach życia społecznego po ukończeniu edukacji. Zmiany systemu edukacji zaowocowały bowiem dalszymi przeobrażeniami. Zasygnalizuję jedynie niektóre $\mathrm{z}$ nich, bowiem ich niezmiernie długa lista byłaby i tak niekompletna.

- Obecnie ponad połowa dzieci z niepełnosprawnością ma prawnie zagwarantowaną, realną możliwość wychowywania się w rodzinie, wzrastania w społeczności lokalnej. 
- Uczeń lub jego rodzice decydują o drodze, miejscu edukacji.

- Uczeń z niepełnosprawnością ma możliwość włączenia się, na poszczególnych etapach rozwoju, w środowisko pełnosprawnych rówieśników i poznanie zasad decydujących o alokacji i społecznym prestiżu w środowisku społecznym.

- Podjęcia i realizacji roli społecznie wartościowej - roli ucznia i rówieśnika w edukacji ogólnodostępnej (niezmiernie istotnej w socjalizacji szkolnej), kształtowania tożsamości osobistej i społecznej oraz zdobywania kompetencji do udziału w życiu społecznym.

- Osoba z niepełnosprawnością ma szanse na zdobycie wykształcenia na porównywalnym z pełnosprawnymi rówieśnikami poziomie.

- Możliwość uruchomienia procesu emancypacji od własnej niepełnosprawności.

Te zmiany niewątpliwie uspokajają. Idea integracji edukacyjnej przekłada się na realne zmiany sytuacji i położenia społecznego osób z niepełnosprawnością w okresie nauki szkolnej.

Dla ogólnodostępnych form edukacji oznacza to zadanie jak najdłuższego utrzymania uczniów ze specjalnymi potrzebami edukacyjnymi $w$ integracyjnych formach edukacji. Wyniki badań i obserwacje wskazują, że szkoły ogólnodostępne i integracyjne nieźle radzą sobie z wyrównywaniem szans edukacyjnych uczniów utrzymania ich w roli ucznia - osoby uczącej się. Niewątpliwą pomocą i wsparciem jest tu ustawa podstawowa MEN z dnia 7 września 1991 r. o systemie oświaty ${ }^{7}$ i odpowiadające im kolejne rozporządzenia Ministra Edukacji Narodowej w sprawie warunków organizowania kształcenia, wychowania i opieki dla dzieci i młodzieży niepełnosprawnej, niedostosowanej społecznie i zagrożonej niedostosowaniem społecznym. Wskazane rozporządzenia uwzględniają również ratyfikowane przez Polskę ważne dla wyrównywania szans edukacyjnych osób z niepełnosprawnością dokumenty międzynarodowe, m.in.: standardy Edukacji dla Wszystkich (Education

${ }^{7}$ Dz. U. z 2004 r. Nr 256, poz. 2572, z późn. zm. 
for $A l l)^{8}$, Deklarację z Salamanki ${ }^{9}$ oraz wytyczne dla działań w zakresie specjalnych potrzeb edukacyjnych, przyjęte przez Światową konferencję Dotyczącą Specjalnych Potrzeb Edukacyjnych: Dostęp i Jakość ${ }^{10}$ oraz w Karcie Praw Osób Niepełnosprawnych ${ }^{11}$. Nie wszystkie z przyjętych rozwiązań okazują się korzystne dla uczniów ze specjalnymi potrzebami, ale to nieco inny problem.

Znacznie gorzej placówki integracyjne radzą sobie ze wspieraniem uczniów z niepełnosprawnością $\mathrm{w}$ roli rówieśnika. Większość badań podejmujących tę problematykę wykazuje niski poziom lub brak jakiejkolwiek integracji ze środowiskiem rówieśniczym uczniów niepełnosprawnych, głównie $\mathrm{w}$ relacjach pozaformalnych. Szczególnie na poziomie edukacji podstawowej i gimnazjum. Izolacja, poczucie wyobcowania, marginalizacja to najczęściej sygnalizowane doświadczenia uczniów $\mathrm{z}$ niepełnosprawnością $\mathrm{w}$ rówieśniczych relacjach ${ }^{12}$.

Integracja edukacyjna jako metoda i cel zarazem nie spełnia więc w tym zakresie swojego zadania, nie sprzyja, mimo założeń i psychologicznych uzasadnień, społecznej integracji pełnosprawnych i niepełnosprawnych uczestników wspólnej edukacji.

\section{Co pozostało niezmienne? Pozorowane działania i ich pozorne efekty}

Sam proces upowszechnienia wspólnej edukacji, praktyczna jego realizacja, jak się wydaje, nie tylko nie unieważniła tradycyjnego

8 Raport Programu „Edukacji dla wszystkich” (2000-2016), http://en.unesco. org/gem-report/report/2015/education-all-2000-2015-achievements-and-challenges [dostęp: 17.04.2017].

${ }_{9}$ Deklaracja z Salamanki oraz wytyczne dla działań w zakresie specjalnych potrzeb edukacyjnych. Salamanka, Hiszpania, 7-10 czerwca 1994 r.

${ }_{10}$ Global citizenship education: Preparing learners for the challenges of the 21st century. Paris: UNESCO, 2014 http:/ / en.unesco.org/gced [dostęp: 17.04.2017].

11 Uchwała Sejmu Rzeczypospolitej Polskiej z dnia 1 sierpnia 1997 r. Karta Praw Osób Niepełnosprawnych (M. P. z 1997 r. Nr 50, poz. 475).

12 J. Lipińska-Lokś, op. cit.; K. Barłóg, op. cit.; G. Dryżałowska, op. cit. 
podziału uczniów na pełno- i niepełnosprawnych (chociaż tych drugich przemianowała na uczniów ze specjalnymi potrzebami), ale je nawet umocniła. Przemianowanie uczniów niepełnosprawnych na uczniów ze specjalnymi potrzebami ponownie skoncentrowało uwage na swoistych problemach i specjalistycznej pomocy jako podstawowym warunku umożliwiającym ich edukację w szkołach ogólnodostępnych.

„Ta koncentracja na potrzebach swoistych może być traktowana, jak stwierdza Grzegorz Szumski ${ }^{13}$, jako podstawowa przyczyna mankamentów integracyjnego kształcenia". Uporczywe uznawanie specjalnych potrzeb za najważniejsze ograniczyło wspólne nauczanie do integracji instytucjonalnej i ostatecznie przesądziło o słabości integracyjnego kształcenia w przeciwdziałaniu wykluczeniu i marginalizacji uczniów niepełnosprawnych w procesie szkolnej edukacji. Ostatecznie zdecydowało o pozorności działań podejmowanych w tym zakresie. Wspieranie, wyrównywanie szans edukacyjnych uczniów z niepełnosprawnością bez wystarczającej troski o przekształcanie postaw społeczności szkolnej (nauczycieli, pełnosprawnych rówieśników i ich rodziców), z negatywnych na akceptujące ich „inność” i odmienność funkcjonalną przyczyniło się także do migracji uczniów $\mathrm{z}$ niepełnosprawnością $\mathrm{z}$ integracyjnych form edukacji do specjalnych.

Raport tematyczny z badania - Realizacja ścieżek edukacyjnych z 2014 r. nie napawa optymizmem. 32\% uczniów ze specjalnymi potrzebami edukacyjnymi przynajmniej raz zmieniło formę edukacji ze szkoły ogólnodostępnej (40\%) lub integracyjnej (60\%) na specjalną. Najczęściej tego rodzaju decyzje są wynikiem nasilenia się porażek szkolnych w obu rolach (ucznia i rówieśnika) w stopniu przekraczającym odporność psychiczną ucznia i jego rodziców, ale także braku właściwej opieki i wsparcia - nieprzestrzegania zaleceń wskazanych w orzeczeniu o potrzebie kształcenia specjalnego. W konsekwencji braku lub nadmiaru działań wyrównujących szanse edukacyjne uczniów z niepełnosprawnością. Jeżeli te informacje

${ }^{13}$ G. Szumski, op. cit., s. 16. 
uzupełnimy o decyzje dyrektorów szkół dotyczące losów edukacyjnych tej grupy uczniów, problem staje się bardziej złożony. $4 \%$ dyrektorów szkół ogólnodostępnych odmówiło przyjęcia do swoich placówek dzieci ze specjalnymi potrzebami edukacyjnymi, wśród nich $20 \%$ do integracyjnych i 8\% do specjalnych, a zmianę szkoły analogicznie rekomendowało 30\% dyrektorów z placówek ogólnodostępnych, $40 \%$ z integracyjnych i $23 \%$ ze specjalnych. Ponadto, jak wynika z „Raportu końcowego: Badania wpływu kierunku i poziomu wykształcenia na aktywność zawodową osób niepełnosprawnych":

połowa przedstawicieli placówek edukacyjnych uważa, iż osoby niepełnosprawne powinny uczyć się w placówkach specjalnych, a co czwarty utrzymuje, iż osoby niepełnosprawne $\mathrm{w}$ ogóle nie nadają się do normalnych szkół, bo nie są w stanie w nich funkcjonować. Średnio co czwarty badany przedstawiciel z otoczenia instytucji edukacyjnej wyraża przekonanie, iż osoby niepełnoprawne w szkole narażone są tylko na stres i nic więcej. Konsekwentnie podobny odsetek uznaje, iż w procesie edukacji powinny być one traktowane ulgowo ${ }^{14}$.

Najchętniej przyjmowanymi do integracyjnych form edukacji (w deklaracjach dyrektorów) są uczniowie $\mathrm{z}$ niepełnosprawnością intelektualną w stopniu lekkim (63\%), słabosłyszący (42\%), słabowidzący $(40 \%)$ z uszkodzeniem narządu ruchu (38\%), autyzmem i Zespołem Aspergera (30\%). Szkołę specjalną jako najlepsze środowisko edukacji uczniów z niepełnosprawnością intelektualną w stopniu umiarkowanym i znacznym wskazało $67 \%$ badanych dyrektorów, dla uczniów niesłyszących 56\%, dla uczniów niewidomych 57\%. Oznacza to, że wciąż mamy segregację w integracyjnym ustroju kształcenia dzieci i młodzieży niepełnosprawnej. Wciąż rodzaj i stopień niepełnosprawności decyduje o przyzwoleniu na wspólną z pełnosprawnymi uczniami edukację. Z danych

14 Badania wpływu kierunku i poziomu wykształcenia na aktywność zawodową osób niepełnosprawnych Raport końcowy, część 1 z 6, Pentor Research International, s. 12/13, https://www.pfron.org.pl/fileadmin/ftp/dokumenty/Badania_i_ana lizy/Raport_CZESC_1z6_final.pdf [dostęp: 2.04.2017]. 
tych wynika, że szkoły ogólnodostępne i integracyjne są otwarte na kształcenie tych uczniów z niepełnosprawnością, których różnice w funkcjonowaniu szkolnym mieszczą się w granicach normy zróżnicowania indywidualnego uczniów, a bronią się przed tymi, którzy wymagają podejmowania działań wykraczających poza standardy, są niezgodne lub wykraczają poza przyzwyczajenia i kompetencje nauczycieli.

Rozproszone, fragmentaryczne dane, odnoszące się do efektywności integracyjnych form kształcenia pozyskiwane $\mathrm{w}$ badaniach skoncentrowanych na diagnozie różnych obszarów życia osób $\mathrm{z}$ niepełnosprawnością to niewystarczające argumenty do odpowiedzialnego stwierdzenia, że integracja edukacyjna w Polsce się nie udała, ale wystarczająca podstawa do refleksji nad argumentami uzasadniającymi takie oceny.

Uczeń (jego rodzice) ma prawo wybrać szkołę, a szkoła ma prawo odmówić jego przyjęcia ze względu na brak „możliwości” zaspokajania jego specjalnych potrzeb edukacyjnych. W efekcie ci uczniowie podejmują edukację niezgodnie z własnymi lub opiekunów oczekiwaniami. Na ile tego typu doświadczenia i decyzje mają znaczenie dla biografii takich uczniów nie sposób ocenić.

Podobna trudność dotyczy rozpoznania strategii podejmowanych przez niektórych nauczycieli i dyrektorów szkół, które służą zniechęcaniu do kontynuowania nauki w integracyjnych formach edukacji tych uczniów, których rodzice taką decyzję podjęli w przekonaniu, że „integracja włączająca (czyli taka, która zakłada, że każde dziecko niepełnosprawne jest pełnoprawnym członkiem szkoły), to jedyny klucz do społeczeństwa, poznawania ludzi i nawiązywania przyjaźni” bądź były wynikiem głębokiego przekonania, że szkoła specjalna "to największe wykluczenie, getto”, "zmarnuje dziecko"15. Powyżej przytoczone dane dotyczące migracji uczniów niepełnosprawnych $\mathrm{z}$ integracyjnych form edukacji do

15 S. Szwed, Sumienie bardzo czyste, [w:] Pytania, których się nie zadaje, red. J. Koral, Wydawnictwo Stowarzyszenie Rodzin i Opiekunów Osób z Zespołem Downa, Warszawa 2012, s. 76. 
szkół specjalnych potwierdzają istnienie tego typu praktyk. Negatywne doświadczenia $\mathrm{z}$ nich wynikające, w połączeniu z odpornością i wrażliwością na nie rodziców oraz ich dzieci, wcześniej lub później doprowadzają do ostatecznego wyleczenia „(nie)dopasowanych" z integracji. I jest to niezbity dowód na pozorność działań podejmowanych $\mathrm{w}$ tym zakresie. $\mathrm{W}$ integracyjnym ustroju edukacji tego typu zdarzenia nie powinny mieć miejsca, a tym bardziej uzyskiwać społecznego przyzwolenia lub akceptacji. Tymczasem, jak wskazują powyżej przytoczone liczby, nie należą do wyjątkowych.

Rodzic ma prawo wybrać szkołę dla swojego dziecka, tym samym na szkole spoczywa obowiązek odpowiedzialności za efekty jego edukacji, dopasowania oferty edukacyjnej do jego potrzeb edukacyjnych, a tymczasem jest odwrotnie. Uczeń musi sprostać standardom edukacyjnym, opanować podstawę programową, dorównać pełnosprawnym rówieśnikom. To oznacza także obowiązek Państwa stworzenia lepszej szkoły. Przygotowanej do pracy z silnie zróżnicowaną populacją uczniów pełno- i niepełnosprawnych. Otwartą na różnice indywidualne $\mathrm{z}$ odpowiednio wykształconą kadrą pedagogów i nauczycieli każdego szczebla edukacji. Wyposażenia wszystkich nauczycieli w takie kompetencje, które umożliwią im podejmowanie działań adekwatnych do specjalnych potrzeb uczniów z niepełnosprawnością i skutecznego ich zaspokajania.

Zaniechania, szczególnie w tej ostatniej kwestii, są raczej poważne. Wystarczy wspomnieć, że znacząca część przyszłych nauczycieli w toku całego okresu studiów nie ma możliwości zapoznania się nawet $\mathrm{z}$ podstawowymi problemami rozwoju, funkcjonowania i ograniczeniami dzieci i młodzieży z różnymi rodzajami i stopniami niepełnosprawności, a którzy są, przynajmniej formalnie, już od niemal czterdziestu lat „równoprawnymi” uczestnikami ogólnodostępnej edukacji. Niedostatki w tych zakresach wciąż będą uruchamiały praktyki zniechęcania „niedopasowanych” i reprodukcję niestandardowych czynników wewnętrznej selekcji szkolnej (np. ze względu na rodzaj lub stopień niepełnosprawności - przykład dyrektorów podany powyżej). 
Swoboda wyboru szkoły przez rodziców lub samych uczniów tworzy także warunki do uaktywniania się czynnika auto selekcji. Wybór specjalnej ścieżki kształcenia nie zawsze jest uzasadniony dobrem dziecka. Czasem wygodą rodziców lub wiarą, że tam (w szkole ogólnodostępnej, integracyjnej) nauczy się, na miarę swoich możliwości, samodzielności, samostanowienia, samoobsługi, zaradności życiowej i społecznej, w miarę „niezależnego” życia.

Ponad połowa uczniów $\mathrm{z}$ niepełnosprawnością pobiera naukę $\mathrm{w}$ szkołach specjalnych. Przy czym warto zauważyć, że odsetek uczniów wybierających tę ścieżkę edukacji wzrasta na kolejnych etapach edukacji. Część z nich zatem nigdy nie „podjęła walki o prawdziwe włączenie do społeczeństwa i najlepszą edukację"16, a część z niej zrezygnowała. Trudno jednak jednoznacznie stwierdzić, że odpowiedzialność za ten fakt spoczywa wyłącznie na szkole ogólnodostępnej. Powód, brak badań w tym zakresie. Nie ma zatem rzetelnej diagnozy przyczyn takich sytuacji.

Rezygnacja z dalszej nauki razem z pełnosprawnymi uczniami jest jednak dodatkowym argumentem na rzecz pozornych działań integracyjnych i integrujących społeczność szkolną z niepełnosprawnymi uczestnikami procesu kształcenia. Uzupełnia go rezygnacja w ogóle z dalszej nauki. Najczęściej przyczyną takiej decyzji jest brak wiary w sens dalszego kształcenia dla polepszenia własnej sytuacji, utrata zapału do dalszej edukacji, strach przed szkołą, stan zdrowia, rzadziej ukończenie zaplanowanej ścieżki edukacyjnej i podjęcie zatrudnienia.

Porażka i ucznia i instytucji. Zawiódł system, bo formę edukacji, która $\mathrm{w}$ założeniu miała za zadanie wyrównywanie szans na społeczną integrację ugruntował jako konieczny i bezwarunkowy efekt wspólnej edukacji - integrację społeczną. Szansa nie oznacza osiągnięcia celu. Pytanie zatem, czy system wywiązał się z tych zobowiązań, które umożliwiają wykorzystanie integracji edukacyjnej dla integracji społecznej osób z niepełnosprawnością lub czy jasno sprecyzował pojęcie integracji społecznej. Jej rozumienie i zróżnicowane

${ }^{16}$ Ibidem, s. 70. 
wymiary społecznych aktywności i zaangażowań potwierdzających słuszność takiej edukacji. W moim przekonaniu nie. Słusznie zauważa Amadeusz Krause17, że „obecnie nie może już być mowy $\mathrm{w}$ pedagogice specjalnej o uniwersalnych dla wszystkich niepełnosprawności prawidłowościach integracyjnych. Musimy je zawsze rozpatrywać w kategorii specyfiki danej niepełnosprawności". Każdorazowo zatem wyznaczać cząstkowe cele zmierzające do możliwego do osiągnięcia przez jednostkę poziomu jej społecznej integracji. Problem ten sygnalizowałam już w 2004 r. w artykule: Integracja edukacyjna a integracja społeczna ${ }^{18}$.

\section{Co powinno się zmienić? Społeczne usytuowanie osób z niepełnosprawnością we współczesnym świecie}

Dotychczasowe doświadczenia ujawniają znaczny rozdźwięk pomiędzy efektami zakładanymi w koncepcji integracyjnej edukacji a tymi, które są uzyskiwane w praktyce pedagogicznej. Wyniki licznych już badań z tego zakresu wskazują na nieprawidłowe relacje społeczne pomiędzy pełno- i niepełnosprawnymi uczniami. Izolacja, odrzucenie, marginalizacja, dyskryminacja, brak poczucia przynależności do zespołu klasowego, to główne doświadczenia uczniów z niepełnosprawnością w trakcie nauki szkolnej ${ }^{19}$. One, jak się wydaje, zaprzeczają idei wspólnej edukacji, niebezpiecznie zagrażają jej kontynuacji. Szczególnie obecnie gdy entuzjazm dla idei integracji edukacyjnej stopniowo maleje, a wzrastają wymogi sprawności, urody, funkcjonalności, które powodują, że niepełnosprawność wciąż i pewnie zawsze będzie postrzegana jako zjawisko negatywne z szeregiem konotacji nią wyzwalanych i przenoszonych na osoby nią obciążone i gdy lęk przed „Innym”, „Obcym”, „Odmiennym" przybiera na sile.

17 A. Krause, niepublikowana recenzja w postepowaniu awansowym, 2017, s. 11.

18 Integracja społeczna osób niepełnosprawnych: (red.) G. Dryżałowska, H. Żuraw:, Wydawnictwo Akademickie „Żak”, Warszawa 2004.

19 J. Lipińska-Lokś, op. cit.; K. Barłóg, op. cit.; G. Dryżałowska, op. cit. 
„Integracja, owszem, to piękna idea, ale powinna pozostać $\mathrm{w}$ sferze teorii. $\mathrm{W}$ przedszkolu było jeszcze bardzo dobrze. [...] W szkole podstawowej idea włączania w społeczeństwo odczarowała się zupełnie. Zobaczyłam absolutną fikcyjność integracji. Nawet $\mathrm{w}$ dobrej szkole, $\mathrm{w}$ dobrej klasie dzieci nie kolegują się ze sobą. Zrozumiałam, że integracji po prostu nie ma, bo ludzie mają tendencję do segregacji" - stwierdza matka ucznia z niepełnosprawnością intelektualnąa20.

Inna widzi ten problem inaczej: „Każdy rodzic boi się samotności swojego dziecka, ale trzeba pamiętać, że odrzucenie nie dotyka tylko osób niepełnosprawnych, ale wszystkich, którzy w jakiś sposób się wyróżniają. [...] Musimy być świadomi, że nasze dziecko jest inne, a to jest szkoła ogólnodostępna"21.

Dosyć trudno w oparciu o powyżej zaprezentowane dane i stwierdzenia wykazać, na ile upowszechnienie integracyjnych form edukacji jest istotnym czynnikiem zmian społecznego usytuowania osób $\mathrm{z}$ niepełnosprawnością we współczesnym świecie, także po ukończeniu edukacji $\mathrm{w}$ dorosłym życiu. To pytanie pozostaje otwarte. Nie wiemy bowiem, jakie znaczenie ma ukryty program szkoły, dla społecznej integracji osób z niepełnosprawnością, jaki ma wpływ na rodzaj doświadczeń szkolnych i uruchamiane mechanizmy przystosowawcze do własnej niepełnosprawności w sferze fizycznej, psychicznej i społecznej przeciwdziałające odrzuceniu lub izolacji społecznej.

Rozproszone dane, różne metodologie stosowane $\mathrm{w}$ ich gromadzeniu także odniesienia do poszczególnych lat i grup osób z niepełnosprawnością $\mathrm{w}$ ich prezentacji są poważną przeszkodą $\mathrm{w}$ formułowaniu jednoznacznych opinii.

Wiemy, jaka jest i jak się zmieniła np. struktura wykształcenia osób z niepełnosprawnością. Od 1988 r. następuje systematyczny wzrost poziomu wykształcenia osób niepełnosprawnych. Znacząco zmienił się odsetek osób najgorzej wykształconych. W 1988 r. ponad

${ }^{20}$ S. Szwed, op. cit., s. 77-80.

${ }^{21}$ Ibidem s. 81. 
dwie trzecie niepełnosprawnych posiadało co najwyżej wykształcenie podstawowe, obecnie wskaźnik ten jest prawie dwukrotnie niższy. Jednak odsetek osób niepełnosprawnych z wyższym wykształceniem rośnie dużo wolniej niż ten sam wskaźnik w grupie osób sprawnych, natomiast stopniowo zaciera się różnica w wykształceniu osób sprawnych i niepełnosprawnych na poziomie średnim. Struktura wykształcenia osób z niepełnosprawnością w wieku 16 lat i więcej w stosunku do ogółu populacji przedstawia się następująco ${ }^{22}$ :

- wyższe - 6\% (16\%)

- policealne i średnie zawodowe - 19\% (23\%),

- średnie ogólnokształcące - 8\% (10\%),

- zasadnicze zawodowe - 30\% (26\%),

- gimnazjum, podstawowe, niepełne podstawowe i bez wykształcenia - 38\% $(24 \%)^{23}$.

Jednocześnie brak danych, ile w danym roku rozpoczęło edukację, ilu jest absolwentów na poszczególnych etapach kształcenia i ilu z nich złożyło egzamin potwierdzający kwalifikacje zawodowe nie pozwala na ocenę efektywności form edukacji i etapów kształcenia dla społecznej integracji osób z niepełnosprawnością. Dostępne, fragmentaryczne dane nie obrazują bowiem rzeczywistej sytuacji. Np. w roku szkolnym 2013/2014 technika ogólnodostępne i specjalne (wraz z uzupełniającymi) ukończyło 448 osób ze specjalnymi potrzebami edukacyjnymi do matury przystąpiło 302, a świadectwo dojrzałości otrzymało 153 lub w 2013/2014 roku było 226 absolwentów szkół policealnych, 44,7\% przystąpiło do egzaminu potwierdzającego kwalifikacje zawodowe, a zdało go niespełna 10\% (GUS). W oparciu o nie można jedynie stwierdzić określoną efektywność tej edukacji dla zmiany poziomu wykształcenia. I jest to zmiana zdecydowanie korzystna.

22 Badania wpływu kierunku i poziomu wykształcenia na aktywność zawodową osób niepełnosprawnych Raport końcowy, Pentor Research International, (źródło: https:/ / www.pfron.org.pl, dostęp: 2.04.2017); x\% osoby niepełnosprawne, (x\%) ogółem Polacy.

${ }^{23} \mathrm{Na}$ podstawie: Badanie finansowane z środków Państwowego Funduszu Rehabilitacji Osób Niepełnosprawnych (na podstawie GUS - BAEL, II kwartał 2009). 
Wykształcenie, $\mathrm{w}$ wielu opracowaniach podejmujących problematykę z tego zakresu ${ }^{24}$, jest podkreślane jako jeden z czynników wyznaczający sytuację osób $\mathrm{z}$ niepełnosprawnością $\mathrm{w}$ różnych obszarach życia społecznego. Najsilniej łączy się w nich poziom wykształcenia z aktywnością zawodową i podkreśla, że im wyższy poziom wykształcenia osób z niepełnosprawnością, tym ich szanse na rynku pracy są większe.

Zależność tę obrazuje wskaźnik zatrudnienia ze względu na poziom wykształcenia dla osób niepełnosprawnych oraz ogółem całej populacji (dane dla osób w wieku 15 lat i więcej) ${ }^{25}$.

- ogółem - 13,3\% (50,4\%),

- wyższe - 27,0 \% (78,4\%),

- średnie zawodowe - 16,9\% (63,3\%),

- średnie ogólnokształcące - 14,1\% (41,1\%),

- zasadnicze zawodowe - 17,4\% $(58,6 \%)$,

- gimnazjalne i niższe - $6,0 \%(17,2 \%)^{26}$.

Szczegółowe analizy uwzględniające związek wykształcenia z aktywnością zawodową i ekonomiczną nie są już jednak tak jednoznaczne. Wprawdzie z powyższych danych wynika, że osoby niepełnosprawne $\mathrm{z}$ wyższym wykształceniem to najliczniejsza grupa aktywnych zawodowo. Powstaje jednak pytanie o rodzaj, stopień orzeczonej niepełnosprawności, czas jej wystąpienia, miejsce zatrudnienia i zajmowane stanowisko, jego adekwatność do uzy-

${ }^{24}$ B. Kołaczek, Aktywność ekonomiczna osób niepetnosprawnych i ich postawy wobec pracy zawodowej, [w:] Sytuacja osób niepetnosprawnych na rynku pracy, IPiSS, Warszawa 2002; M. Garbat, Aktywność i aktywizacja zawodowa osób niepetnosprawnych, [w:] Aktywizacja zawodowa osób niepetnosprawnych, 2-3, Krajowa Izba Gospodarczo-Rehabilitacyjna, Warszawa 2007; Zatrudniając niepełnosprawnych. Wiedza, opinie i doświadczenia pracodawców, red. B. Gąciarz, E. Giermanowska, Instytut Spraw Publicznych, Gdynia 2009.

${ }^{25}$ Badania wpływu kierunku i poziomu wykształcenia na aktywność zawodową osób niepełnosprawnych Raport końcowy, Pentor Research International, (źródło: https:/ / www.pfron.org.pl, dostęp: 2.04.2017); x\% osoby niepełnosprawne, (x\%) ogółem Polacy.

26 Źródło: Badanie finansowane z środków Państwowego Funduszu Rehabilitacji Osób Niepełnosprawnych (na podstawie GUS - BAEL, II kwartał 2009). 
skanych kwalifikacji tej grupy osób z niepełnosprawnością. Bez uwzględnienia tych danych twierdzenie, że poziom wykształcenia jest decydującym czynnikiem ich zatrudnienia, jest nieuprawnione. Z większym prawdopodobieństwem można przyjąć, że jest to grupa o mniejszych ograniczeniach funkcjonalnych, lepszej kondycji zdrowotnej i wysokich kompetencjach społecznych. Podstawą takiej interpretacji jest fakt, że 70,3\% osób niepełnosprawnych z wyższym wykształceniem nie znajduje się jednak na rynku pracy, chociaż wybrany kierunek studiów ukończyło. Mają zawód i dyplom go potwierdzający, ale nie podjęli zatrudnienia. Problem w tym, czy jest to ich własna decyzja?

W ocenach efektów integracji edukacyjnej nie zawsze jesteśmy szczerzy. Nie próbujemy nawet udzielić odpowiedzi na pytania: czy wszystkie osoby niepełnosprawne powinny/muszą być zintegrowane i zintegrowane na jednakowym poziomie? Czy integracja społeczna, w jej powszechnym rozumieniu, jest dostępna dla wszystkich? Wiemy, że nie, ale nie chcemy tego przyznać, jasno tego stwierdzić, chociaż sami też doświadczamy i odrzucenia i niechęci w różnych gremiach społecznych, mimo że jesteśmy sprawni. Decydują kryteria społecznej selekcji i posiadane kompetencje do podejmowania i realizacji różnych ról i zadań w nie wpisanych. W odniesieniu do osób z niepełnosprawnością także i ignorowanie tego faktu jest hipokryzją szkodzącą idei integracji. Niepełnosprawność wciąż, mimo powoli zachodzących zmian w społecznej percepcji osób nią obciążonych, jest podstawowym kryterium i selekcji i alokacji społecznej osób z niepełnosprawnością, zwłaszcza w bliższych relacjach interpersonalnych, chociaż poprawnością polityczną i optymistyczną prezentacją wskaźników np. aktywności zawodowej, stopy bezrobocia, wykształcenia osób z niepełnosprawnością próbuje się ten niewygodny fakt przesłonić.

Od 2007 r. obserwujemy stopniowy wzrost współczynnika aktywności zawodowej osób niepełnosprawnych do 27,5\% w 2012 r. i utrzymywanie się jego wartości na stabilnym poziomie około $27 \%$ w latach 2013-2014. Mimo spadku w 2015 r. do poziomu 25,9\% wskaźnik ten wzrósł w roku 2016 i osiągnął wartość 26,8\%. Jednak 
dla osób niepełnosprawnych w wieku 16 lat i więcej w 2016 r. sytuacja na rynku pracy kształtowała się następująco: współczynnik aktywności zawodowej wynosił 16,3\%, wskaźnik zatrudnienia $14,6 \%$, stopa bezrobocia $-10,9 \%$.

Zatem ogółem zaledwie 14,6\% osób niepełnosprawnych według tych danych znalazło zatrudnienie. To niepokojące dane, zaprzeczające równości szans osób niepełnosprawnych w tym najważniejszym dla każdego człowieka obszarze życia. Decydującym o samostanowieniu, samodzielności, potwierdzającym podjęcie obowiązań dorosłości. Pozostałe powyżej przedstawione wskaźniki uprawomocniają to stwierdzenie nawet wówczas, gdy odwołamy się do bardziej optymistycznych danych GUS z III kwartału 2011 r.

Według nich na 3,4 mln osób z prawnie orzeczoną niepełnosprawnością 2,1 mln było $\mathrm{w}$ wieku produkcyjnym, ale pracowało w tym czasie 465 tys. czyli 27,3\%, podczas gdy w UE wskaźnik zatrudnienia osób niepełnosprawnym wynosił około 50\%. I chociaż w przywołanym raporcie sformułowano szereg wniosków wynikających z pogłębionej analizy statystycznej zebranych informacji, to uwzględnione $\mathrm{w}$ nich zmienne nie $\mathrm{w}$ pełni obrazują rzeczywisty wpływ/znaczenie poziomu wykształcenia na efektywność integracyjnej edukacyjnej dla włączania tej grupy osób, w ważne społecznie wartościowe obszary życia społecznego po ukończeniu edukacji - w dorosłym życiu. Podkreślają raczej niedoskonałość rozwiązań aktywizujących zatrudnianie osób z niepełnosprawnością.

W raporcie znajduje się także bardzo interesujący wniosek „badania wykazały, iż większą szansę na wykonywanie pracy w wyuczonym zawodzie mają osoby kroczące powszechną ścieżką edukacji, niż osoby uczące się przede wszystkim w szkołach specjalnych. Te ostatnie częściej wybierają też pracę na chronionym rynku pra$\mathrm{cy}^{\prime \prime 27}$. Nie kwestionując słuszności tego wniosku bez rozpoznania struktury społecznej osób podejmujących edukację w integracyj-

27 Badania wpływu kierunku i poziomu wykształcenia na aktywność zawodową osób niepełnosprawnych Raport końcowy, Pentor Research International, (źródło: https:/ / www.pfron.org.pl, dostęp: 2.04.2017), s. 18. 
nych i specjalnych formach edukacji, stwierdzenie to, bez uwzględnienia zmiennych, o których była mowa powyżej i tzw. SES, nie tylko jest na wysokim poziomie ogólności, ale także nie obrazuje czynników, które o tym decydują. Zwraca na ten fakt uwagę Grzegorz Szumski28, gdy odwołując się do wyników badań polskich i zagranicznych badaczy ${ }^{29}$, wskazuje na udowodnione mechanizmy selekcji społecznej zapewniające lepsze miejsca dzieciom wychowywanym w rodzinach o wyższym statusie społeczno-ekonomicznym i dość silny związek między SES rodziny a miejscem kształcenia dziecka. $Z$ jego analiz tego problemu wynika, że do klas integracyjnych trafia $40 \%$ uczniów z wysokim i niespełna 20\% z niskim SES, podczas gdy do szkół specjalnych uczęszcza prawie $50 \%$ uczniów ze środowiska o niskim i około $25 \%$ z wysokim SES 30 . Ta zaobserwowana tendencja zwraca uwagę na SES środowiska rodzinnego niepełnosprawnych uczniów także w aspekcie nierówności edukacyjnych, które mogą być jej konsekwencją - powodować je, wzmacniać lub osłabiać, w efekcie kształtować ich sytuację na rynku pracy i decydować o społecznej alokacji.

Wiele uwagi nierównościom edukacyjnym (definiowanym jako korelacja między statusem przypisanym ucznia a jego osiągnieciami szkolnymi) związanym ze statusem ekonomiczno-społecznym rodziny pochodzenia ucznia poświęcił Roman Dolata ${ }^{31}$. Analiza prze-

${ }^{28}$ G. Szumski, Edukacja włączająca - niedokończony projekt, „Ruch Pedagogiczny” 2014, nr 4.

${ }^{29}$ K. Parys, S. Olszewski, Dla kogo integracja?, [w:] Dyskursy Pedagogiki Specjalnej 2. Konteksty teoretyczne, red. E. Górniewicz, A. Krause, Wydawnictwo Uniwersytetu Warmińsko-Mazurskiego, Olsztyn 2003; A. Dyson, Special needs in the twenty-first century: where we're been and where we're going. "British Journal of Special Education” 2001, 28(1); M. Eckhart, U. Haeberlin, C.S. Lozano, P. Blanc, Langzeitwirkung der schulischen Integration. Haupt Verlag, Bern-Stuttgart-Wien 2011; J.O. Myklebust, F.O. Båtevik, Earning a living for former students with special educational needs. Does class placement matter?, „European Journal of Special Needs Education” 2009, nr 2.

${ }^{30}$ G. Szumski, Efekt skupienia. W jaki sposób światta zasada przyczynia się do edukacyjnego wykluczenia, "Chowanna” 2012,1(38).

31 R. Dolata, Szkoła - segregacje - nierówności, Wydawnictwa Uniwersytetu Warszawskiego, Warszawa 2008. 
prowadzonych przez niego dwóch badań uprawdopodobniła twierdzenie, że „na poziomie systemów oświaty obserwujemy dodatnią korelację między poziomem segregacji społecznych a natężeniem nierówności edukacyjnych"32. W tym kontekście i w odniesieniu do różnych form kształcenia uczniów niepełnosprawnych powstaje pytanie o znaczenie statusu przypisanego, związanego $\mathrm{z}$ pozycją $\mathrm{w}$ strukturze społecznej rodziny dziecka $\mathrm{z}$ realnym dostępem, przebiegiem i efektami jego edukacji. W konsekwencji jest to pośrednio pytanie o to, czy obecny, trzyścieżkowy system kształcenia uczniów niepełnosprawnych jest systemem równych szans i jakie ma znaczenie dla ich społecznej alokacji w dorosłym życiu.

Podstawową funkcją szkoły jest selekcja (patrz: teoria strukturalno-funkcjonalna Parsonsa z 1969 r.). Szkoła ma zatem za zadanie takie zróżnicowanie uczniów by umożliwić racjonalne alokowanie zasobów ludzkich w strukturze społecznej.

Osiągnięcia szkolne są podstawą decyzji selekcyjnych, a szkoła realizując funkcję selekcyjną, współkształtuje tożsamość społeczną jednostki ${ }^{33}$.

Pytanie pierwsze - jaką tożsamość społeczną uzyskują uczniowie ze specjalnymi potrzebami edukacyjnymi (kształceni w integracyjnych i specjalnych formach edukacji) i z jaką wkraczają w dorosłość? Czy obrana ścieżka edukacji wyposaża ich w te kompetencje, które są niezbędne do projektowania własnej biografii, przygotowuje do zaplanowania własnego życia? I drugie, ważniejsze pytanie, czy osiągnięcia szkolne uczniów z niepełnosprawnością mają znaczenie dla ich społecznej alokacji na równych z pełnosprawnymi członkami społeczeństwa zasadach? Czy uruchamiają mechanizmy emancypacji od własnej niepełnosprawności, łagodzą jej opresyjność. Stają się, dla samych osób z niepełnosprawnością podstawą „uwalniania się” od ograniczeń nią spowodowanych na rzecz budowania siebie jako osoby, której przymioty własne decydują o tym, kim jest i jaka jest dla siebie i innych.

32 Ibidem, s. 149.

33 Ibidem. 
Uzyskanie odpowiedzi na te pytania wymaga pogłębionych analiz i rzetelnej oceny sytuacji osób niepełnosprawnych w trakcie edukacji, na rynku pracy, w życiu rodzinnym, sposobach spędzania wolnego czasu czy wreszcie badań porównawczych nad tożsamością, jakością życia osób z integracyjnych i segregacyjnych form kształcenia (w obu wymiarach: obiektywnym i subiektywnym) i w oparciu o nie ocenianie integracyjnej edukacji jako metody oraz skuteczności działań w niej podejmowanych dla osiągania założonego celu - społecznej integracji osób pełno i niepełnosprawnych w trakcie i po ukończeniu edukacji - w dorosłości.

Problem wydaje się ważniejszy, jeżeli uwzględnimy podzielenie, w wyniku upowszechnienia integracyjnych form edukacji, środowiska osób z niepełnosprawnością według innego od do niedawna funkcjonującego kryterium (opartego o rodzaj i stopień niepełnosprawności) na tych z integracyjnych form edukacji „normalsów” i „specjalnych", często z głębszym stopniem niepełnosprawności lub wielorako, głęboko niepełnosprawnych. Takie podzielenie środowiska osób z niepełnosprawnością zmienia sytuację społeczną i jednych i drugich. Tworzy nowe problemy społeczne w konsekwencji nowe wyzwania w projektowaniu modeli pomocowych przeciwdziałających ich społecznej marginalizacji, dyskryminacji, również we własnym środowisku - w społeczności osób $\mathrm{z}$ niepełnosprawnością.

Potwierdzenia tego faktu dostarczają badania Moniki Skury34. Wyniki poczynionych analiz dowodzą, że badani (z uszkodzonym narządem ruchu)

w kontaktach $z$ innymi ludźmi przejmują obowiązujące opinie i nastawienia. Nie są zatem niezależni i gotowi, aby otworzyć się na drugą osobę bez zapośredniczenia $\mathrm{w}$ tym, jak ocenia i traktuje je otoczenie [...] sami obciążeni psychospołecznymi trudnościami wynikającymi z doświadczania własnej niepełnosprawności nie rozważają możliwości wzięcia na siebie odpowiedzialności za inne osoby ${ }^{35}$.

${ }^{34}$ M. Skura, Ja - Inny. Relacje społeczne osób z (nie)petnosprawnością, Wydawnictwa Uniwersytetu Warszawskiego, Warszawa 2016.

35 Ibidem, s. 172. 
Za innych niepełnosprawnych, również z tym samym jak i innym rodzajem niepełnosprawności.

Integracja edukacyjna okazała się więc bardziej bezradna wobec kryteriów społecznej selekcji i alokacji osób z niepełnosprawnością niż zakładano. Dyskryminacja osób z niepełnosprawnością, mimo dużego, w ostatnich dziesięcioleciach, wysiłku różnych gremiów i znaczących nakładów finansowych jest wciąż dominującym doświadczeniem osób z niepełnosprawnością, a integracja społeczna tak jak przed upowszechnieniem integracji edukacyjnej, tak i obecnie dla wielu osób z niepełnosprawnością w ogóle nie jest możliwa. Także dla tych którzy zdobyli wykształcenie w integracyjnych lub ogólnodostępnych szkołach. Wielu, nawet w cząstkowych segmentach społeczeństwa, jest nadal nieobecna lub niechętnie przyjmowana, również we własnych grupach odniesienia, chociaż prawdziwy sens integracji społecznej wyraża się w dążeniu do społecznego włączania osób z niepełnosprawnością poza obszarem szkoły.

Umiejętność otwarcia się na inność drugiego człowieka, chęć podejmowania dialogu oraz rozwiązywanie dylematów dotyczących obecności innej osoby są również nieodzowną częścią samoświadomości społecznej osoby oraz - jak napisała Skura - ważnym czynnikiem jej samostanowienia. Zgoda na obecność innego i osobiste zaangażowanie w spotkanie wiąże się z doświadczaniem relacji z tymi, którzy pojawiają się obok, we wspólnej przestrzeni społecznej ${ }^{36}$.

W kontekście powyższego stwierdzenia przyczyną utrzymującej się dyskryminacji, braku powszechnego przyzwolenia na współudział osób z niepełnosprawnością w różnych segmentach życia społecznego jest samoświadomość społeczna, niewystarczające umiejętności sprawnych i niepełnosprawnych członków społeczeństwa do otwarcia się na inność drugiego człowieka i jej akceptację. I nie jest to jedynie „zasługą" integracyjnej edukacji. Raczej nadmiernego optymizmu towarzyszącego upowszechnianiu integracyjnych form

${ }^{36}$ Ibidem, s. 172. 
kształcenia, że integracja edukacyjna zredukuje różnorodność uczestników wspólnej edukacji, spowoduje ich „unifikację i ograniczy stopnie swobody", ale też zmieni w zintegrowanym systemie społecznym powszechne znaczenie niepełnosprawności i osób nią obarczonych. Podwyższy poziom ich „usamodzielnienia” - zdolność do projektowania własnej biografii, odpowiedzialność za własne życie. Przygotuje do dokonywania wyborów w zróżnicowanych propozycjach uczestnictwa i podejmowania wartościowych ról społecznych, przynależności do różnych grup społecznych oraz akceptacji uzyskiwanego w nich znaczenia. Dopóki nie przyznamy wprost, że część osób z niepełnosprawnością nigdy tego nie osiągnie, a część będzie do tego zdolna w ograniczonym zakresie, dopóty wciąż będą formułowane wobec integracji edukacyjnej zarzuty pozorowanych działań i ich pozornych efektów.

\section{Jakie zmiany są konieczne? Pomoc w aspekcie personalnym i społecznym}

Oczekiwane zmiany jednak nie zależą jedynie od tego, co dzieje się w szkole, równie ważny jest społeczny kontekst i wielość czynników modelujących warunki życia i funkcjonowanie każdej osoby dla uzyskania lub zmiany dotychczasowej tożsamości społecznej $\mathrm{np}$. $\mathrm{z}$ osoby niepełnosprawnej na osobę $\mathrm{z}$ niepełnosprawnością, umiejętności jej negocjowania w społecznych relacjach, ujawniania własnej podmiotowości i żądania prawa do jej uszanowania. One mają znaczenie dla przebiegu procesu i osiąganego poziomu integracji społecznej. Dorosłe życie toczy się poza szkołą. Dorosłość nie jest wyznaczana sprawnością, więc niepełnosprawność nie może być jej zaprzeczeniem. Niepełnosprawność nie może zatem usprawiedliwiać odmowy przyjęcia do pracy, prawa do samodzielnego życia, założenia rodziny, do samostanowienia o sobie czy wreszcie wyboru środowiska życia. Nie może być przeszkodą w integracji społecznej i akceptacji możliwych, zróżnicowanych jej poziomów wyznaczonych rodzajem i stopniem niepełnosprawności. 
Do skutecznej realizacji integracji społecznej osób z niepełnosprawnością, zdaniem Otto Specka ${ }^{37}$, „potrzebne jest stymulowanie całego społeczeństwa (osób pełno i niepełnosprawnych) w kierunku aktywnej gotowości do integracji". Potrzebne są takie działania w których integracja społeczna jest wyraźnym celem wychowawczym - pomocą $w$ aspekcie personalnym i społecznym.

W pierwszym z nich, jak stwierdza, chodzi o wychowanie człowieka pozostającego w zgodzie ze sobą i akceptującego samego siebie. O integrację personalną i społeczną zarazem, jako wzajemnie się warunkujące, dwie strony jednego i tego samego zadania pedagogicznego. „Adekwatność integracji społecznej wynika z doświadczenia integracji personalnej [...] zintegrowanym społecznie jest się wtedy, gdy pozostaje się w stanie równowagi wewnętrznej. Analogicznie - w stopniu, w jakim człowiek czuje się pewny i silny - wzrastają możliwości i szanse $\mathrm{w}$ procesie społecznego uczestnictwa" 38 .

Przyjąć można, że edukacja integracyjna poprawnie wywiązała się z tego zadania przynajmniej wobec swoich absolwentów z niepełnosprawnością. $\mathrm{W}$ drugim natomiast o "celowe kształtowanie wspierających kontaktów społecznych, postaw i gotowości pełnosprawnych do społecznej integracji z osobami z niepełnosprawnością"39. W nich można upatrywać możliwości zmiany kryteriów społecznej selekcji i „upowszechnianie zgody na koegzystencję ludzi pełno i niepełnosprawnych" 40 . Tutaj wspólna edukacja okazała się niewystarczająca. Zaniedbanie działań pomocowych (przede wszystkim w aspekcie społecznym), w procesie upowszechniania integracyjnych form kształcenia uczniów z niepełnosprawnością są bezpośrednią przyczyną negatywnych ocen integracyjnej edukacji

${ }^{37}$ O. Speck, Niepetnosprawni w społeczeństwie. Podstawy ortopedagogiki, Gdańskie Wydawnictwo Psychologiczne, Gdańsk 2005, s. 91.

38 Ibidem.

${ }^{39}$ Ibidem, s. 400.

${ }^{40}$ A Krause., Współczesne paradygmaty pedagogiki specjalnej, Oficyna Wydawnicza „Impuls”, Kraków 2010, s. 154. 
(jako metody) i zarzutów formułowanych w odniesieniu do uzyskiwanych, raczej postulowanych niż rzeczywistych, efektów (celu) wspólnej edukacji uczniów pełno- i niepełnosprawnych, dla ich społecznej integracji.

Zmiany są więc potrzebne i konieczne, ale bardzo niewielka jest szansa, że dokona ich sama szkoła, bo jak napisał Speck"1, sens instytucjonalnie zorganizowanej integracji społecznej zostanie nadany dopiero wówczas, gdy będzie dążyła do włączenia społecznego osób $\mathrm{z}$ niepełnosprawnością poza obrębem szkolnym, np. do integracji rówieśniczej, zawodowej, wspólnot lokalnych. Są to naturalne społeczne procesy włączania. Za nie odpowiadają postawy, a więc rzeczywiste hierarchie wartości społecznie wyznawane i preferowane i to one wyznaczają znaczenie jakie ma wspólnota w nauce, zabawie i pracy dla pełno- i niepełnosprawnych członków społeczeństwa. Integracyjny cel wychowawczy musi więc mieć dla obu społeczności, (pełnosprawnej i niepełnosprawnej) to samo znaczenie przekładające się na rzeczywiste ich zbliżenie.

Wychowanie jako pomoc w społecznej integracji, celowe kształtowanie wspierających kontaktów społecznych, postaw i gotowości pełnosprawnych do społecznej integracji $\mathrm{z}$ osobami $\mathrm{z}$ niepełnosprawnością $\mathrm{w}$ naszym kraju, poza przekazami medialnymi i społecznymi kampaniami reklamowymi jest wciąż nieobecne. One jednak mają niewielkie znaczenie dla przeciwdziałania wykluczaniu osób z niepełnosprawnością z różnych przestrzeni życia społecznego i afirmacji ich obecności w różnych obszarach społecznej przestrzeni. Jednakże, jak stwierdza Antonina Ostrowska ${ }^{42}$, nawet "pozorna akceptacja", zgodnie z teorią normalizacji Freda Davisa, prowadzi do kolejnych etapów normalizacji niepełnosprawności sprzyjających ich pełniejszej integracji społecznej a obecny, równościowy dyskurs społeczny, jeżeli nawet jest wynikiem oczekiwanej poprawności, jest etapem na drodze do inkluzji społecznej, równo-

${ }^{41}$ O. Speck, op. cit.

42 A. Ostrowska, (Nie)petnosprawni w społeczeństwie 1993-2013, Wydawnictwo Instytutu Filozofii i Socjologii Polskiej Akademii Nauk, Warszawa 2015, s. 286. 
prawnego uczestnictwa osób z niepełnosprawnością w głównym nurcie życia społecznego. W ujęciu O. Specka ${ }^{43}$ etapem tożsamym z kształtowaniem inkluzyjnego społeczeństwa. Postulowane przez Specka działania wpisują się w cel globalnej edukacji obywatelskiej - kształtowanie szacunku do innych i poczucia przynależności do globalnej wspólnoty ${ }^{4}$. W globalnej edukacji obywatelskiej jest zatem szansa na renegocjowanie kryteriów społecznej integracji osób niepełnosprawnych.

\section{Zakończenie}

W pedagogice społecznej pojęcie globalnej edukacji obywatelskiej jest powszechnie stosowane, a w pedagogice specjalnej ograniczone do edukacji włączającej (inkluzyjnej). Szczególnie w naszym kraju, gdzie wciąż edukacja włączająca (inkluzyjna) jest postrzegana i realizowana jako "rozszerzona” forma integracji edukacyjnej, umożliwiająca kształcenie uczniów z niepełnosprawnością w każdej ogólnodostępnej placówce i wyrównywanie ich szans edukacyjnych poprzez indywidualne programy terapeutyczne, natomiast kształtowanie inkluzyjnego społeczeństwa jest wciąż nieobecne.

Obiektywna ocena skuteczności integracji edukacyjnej dla społecznej wyłącznie z jednej perspektywy - oceny efektów uzyskiwanych przez absolwentów tej formy kształcenia, bez kształtowania gotowości społecznej do ich integracji nie jest możliwa. Uruchomienie „windy” integracyjnego kształcenia obliguje do wypracowania skutecznych mechanizmów ich włączania w społeczność szkolną, bo dotychczasowe okazują się albo niewystarczające, albo nieskuteczne. I to jest zadanie integracyjnych form edukacji, bowiem „prawdziwe” życie zaczyna się w szkole.

${ }^{43}$ O. Speck, op. cit.

44 10.Global citizenship education: Preparing learners for the challenges of the 21st century. Paris: UNESCO, 2014. http://en.unesco.org/gced [dostęp: 17.04. 2017]. 


\section{Bibliografia}

Analiza sytuacji osób niepetnosprawnych w Polsce i Unii Europejskiej Raport przygotowany w ramach projektu "Zatrudnienie osób niepetnosprawnych - perspektywy wzrostu" Projekt wspólfinansowany ze środków Państwowego Funduszu Rehabilitacji Osób Niepetnosprawnych, red. E. Kryńska, Instytut Pracy i Spraw Socjalnych, Warszawa 2013.

Barłóg K., Wspomaganie rozwoju dzieci z niepetnosprawnościa intelektualna w stopniu lekkim w różnych formach edukacji wczesnoszkolnej, Wydawnictwo Uniwersytetu Rzeszowskiego, Rzeszów 2008.

Człowiek z niepetnosprawnościa w przestrzeni społecznej, red. Z. Gajdzica, Oficyna Wydawnicza „Impuls”, Kraków 2009.

Dolata R., Szkoła - segregacje - nierówności, Wydawnictwa Uniwersytetu Warszawskiego, Warszawa 2008.

Dryżałowska G., Integracja edukacyjna a integracja społeczna, [w:] Integracja społeczna osób niepetnosprawnych, red. G. Dryżałowska, H. Żuraw, Wydawnictwo Akademickie "Żak", Warszawa 2004.

Dryżałowska G., Integracja edukacyjna a społeczna. Satysfakcja z życia osób niedostyszacych, Wydawnictwa Uniwersytetu Warszawskiego, Warszawa 2015.

Firkowska-Mankiewicz A., Spór o inteligencję człowieka. Dziedziczność czy środowisko, Wydawnictwo Polska Akademia Nauk. Instytut Filozofii i Socjologii, Warszawa 1993.

Garbat M., Aktywność i aktywizacja zawodowa osób niepetnosprawnych, w: Aktywizacja zawodowa osób niepetnosprawnych, 2-3, Krajowa Izba Gospodarczo-Rehabilitacyjna, Warszawa 2007.

Gąciarz B., Giermanowska E., Zatrudniając niepetnosprawnych. Wiedza, opinie $i$ doświadczenia pracodawców, Instytut Spraw Publicznych, Warszawa 2009.

Global citizenship education: Preparing learners for the challenges of the 21st century. Paris: UNESCO, 2014. http://en.unesco.org/gced [dostęp: 17.04.2017].

Golinowska S., Topińska I., Pomoc społeczna zmiany $i$ warunki skutecznego działania, Centrum Analiz Społeczno-Ekonomicznych, Warszawa 2002.

Kołaczek B., Aktywność ekonomiczna osób niepetnosprawnych i ich postawy wobec pracy zawodowej, [w:] Sytuacja osób niepetnosprawnych na rynku pracy, IPiSS, Warszawa 2002.

Krause A., niepublikowana recenzja w postepowaniu awansowym, 2017.

Krause A., Wspótczesne paradygmaty pedagogiki specjalnej, Oficyna Wydawnicza „Impuls", Kraków 2010.

Krzychała S., Ryzyko własnego życia. Indywidualizacja w późnej nowoczesności, Wydawnictwo Naukowe DSW, Wrocław 2007.

Lipińska J., Układ stosunków emocjonalno-społecznych między dziećmi w integracyjnych klasach szkolnych, [w:] Z teorii i badań społecznej integracji dzieci niepetnosprawnych, red. A. Maciarz, Oficyna Wydawnicza „Impuls”, Kraków 1999. 
Lipińska-Lokś J., Zmiany stosunków między dziećmi petnosprawnymi i dziećmi z niepetnosprawnościa w klasach integracyjnych, Wydawnictwo Uniwersytetu Zielonogórskiego, Zielona Góra 2011.

Łysek J., Kształcenie integracyjne w Polsce $i$ w krajach Unii Europejskiej, „Nauczyciel i Szkoła" 2002, nr 1-2.

Obwieszczenie Marszałka Sejmu Rzeczypospolitej Polskiej z dnia 19 listopada 2004 r. w sprawie ogłoszenia jednolitego tekstu ustawy o systemie oświaty, Dz. U. z 2004 r. Nr 256, poz. 2572.

Ostrowska A., (Nie)petnosprawni w społeczeństwie 1993-2013, Wydawnictwo Instytutu Filozofii i Socjologii Polskiej Akademii Nauk, Warszawa 2015.

Popławska J., Sierpińska B., "Zacznijmy razem” - dzieci specjalnej troski w szkole podstawowej. Poradnik dla nauczycieli szkót integracyjnych, WSiP, Warszawa 2001.

Skura M., Ja - Inny. Relacje społeczne osób z (nie)petnosprawnością, Wydawnictwa Uniwersytetu Warszawskiego, Warszawa 2016.

Speck O., Niepetnosprawni w społeczeństwie. Podstawy ortopedagogiki, Gdańskie Wydawnictwo Psychologiczne, Gdańsk 2005.

Strategia na rzecz inteligentnego i zrównoważonego rozwoju sprzyjającego włączeniu społecznemu, Komunikat Komisji KOM, Komisja Europejska, Bruksela 2010.

Szumski G., Edukacja włączająca - niedokończony projekt, "Ruch Pedagogiczny” 2014, nr 4.

Szumski G., Wokót edukacji włączającej. Efekty kształcenia uczniów z niepetnosprawnościa intelektualna w stopniu lekkim w klasach specjalnych, integracyjnych i ogólnodostępnych, Wydawnictwa Akademii Pedagogiki Specjalnej im. Marii Grzegorzewskiej w Warszawie, Warszawa 2010.

Szwed S., Sumienie bardzo czyste, [w:] Pytanie których się nie zadaje, red. J. Koral, Wydawnictwo Stowarzyszenie Rodzin i Opiekunów Osób z Zespołem Downa, Warszawa 2012.

https://www.pfron.org.pl/download/5/503/04-KrystynaSlany.pdf https://www.pfron.org.pl/download/1/7777/RaportCZESC1z6final.pdf www.niepelnosprawni.gov.pl/p,122,zrodla-danych-o-osobach-niepelnosprawnych http://www.niepelnosprawni.gov.pl/niepelnosprawnosc-w-liczbach-/dane-demo graficzne /informacje i dane demograficzne/ Badanie zdrowia ludności Polski w 2009 r.

http://www.stat.gov.pl/bdl/app/strona.html?p_name=indeks-dane pobierane w okresie 1.04-12 maja $2017 \mathrm{r}$.

https://www.pfron.org.pl/download/5/503/04-KrystynaSlany.pdf https://www.pfron.org.pl/download/1/7777/RaportCZESC1z6final.pdf 